\title{
RENAL FUNCTION AS A FACTOR IN THE URINARY EXCRETION OF ASCORBIC ACID
}

\author{
By JULIUS SENDROY, JR.,1 AND BENJAMIN F. MILLER 2 \\ (From the Hospital of the Rockefeller Institute for Medical Research, New York City)
}

(Received for publication October 11, 1938)

The demonstration by Harris, Ray, and Ward (1) of a correlation between the urinary excretion of ascorbic acid and the dietary intake has led to many investigations of ascorbic acid metabolism based on the technique suggested by these authors. Sendroy and Schultz (2) have given especial attention to some of the possible factors affecting tests based on urinary excretion values. A urinary excretion test might also be affected by another factor, namely, that of kidney function.

The difference between the ascorbic acid in the test dose and the amount in the urinary output has been ascribed either to a deficiency, leading to storage, or to an increased destruction of the material in the body. Nevertheless, it might be increased, especially in disease, by a lowered excretion rate. In the great majority of nutrition studies, there has probably been little error involved in the neglect of this factor, or in the tacit assumption that renal function was unvarying or normal in the cases observed. However, since such tests may and, indeed, have been applied under conditions where kidney function was undoubtedly abnormal, it seemed desirable to investigate the effect of this factor and to learn something of the mode of renal excretion of ascorbic acid.

Drigalski (3), who studied a variety of pathological conditions, among which were Addison's disease, acute nephritis, and nephrosis (but one case in each condition), concluded that the excretion of ascorbic acid in the urine was independent of changes in kidney function with respect to glomerular or tubular damage. Siwe (4) studied one case of Addison's disease and found a decreased excretion of ingested ascorbic acid. Shortly thereafter, Wilkinson, Manch, and Ashford (5), studied the ascorbic acid urine excretion of three women with Addison's disease, and observed a poor response to test doses.

1 Present address-Department of Medicine, Loyola University School of Medicine, Mercy Hospital, Chicago.

2 Present address-University of Chicago, Chicago.
They concluded that the degree of ascorbic acid subnutrition in their cases paralleled the severity of the disease. However, they did not take into consideration the possibility that their results indicated not a disturbance of ascorbic acid metabolism but a functional renal insufficiency, which is one of the well known characteristics of Addison's disease.

Van Eekelen's (6) observation that a surplus excretion of ascorbic acid occurs in the urine when the blood level of about $1.3 \mathrm{mgm}$. per 100 cc. is exceeded, seems to have been the first indication that a renal threshold was involved. Lund (7) and Faulkner and Taylor (8) have also concluded that the ascorbic acid concentration in the urine is dependent on the serum concentration. The latter authors found a threshold level of about $1.4 \mathrm{mgm}$. per $100 \mathrm{cc}$. of serum. Because of the unknown effect of renal impairment on urinary excretion, Wright, Lilienfeld, and MacLenathen (9) have advocated, as a criterion of nutritional saturation of ascorbic acid, a study of the blood curve in addition to measurement of the urinary excretion, after intravenous injection of ascorbic acid. More recently, Wright and MacLenathen (10) have studied a patient who had malignant hypertension, with a nitrogen retention definitely indicative of a diminished renal function. This individual, despite a history of adequate ascorbic acid intake, showed a distinct retention of the injected test dose. The low output in the urine, usually a sign of subnutrition, could therefore be attributed to kidney damage.

On the basis of simultaneous ascorbic acid and inulin clearances in man (in presumably normal individuals) over a wide range of plasma ascorbic acid concentrations, Friedman, McGoey, and Ralli (11), and Ralli, Friedman, and Rubin (12) have found further evidence of the threshold nature of ascorbic acid renal excretion.

The present paper is concerned with a quantitative study of the effect of various degrees of 
renal impairment on the urinary excretion of ascorbic acid in man. The excretion after the administration of large test doses was determined under conditions as normal as possible with respect to the nutritional and metabolic factors affecting the test. The urinary output was then directly correlated with renal function, which was subsequently determined by simultaneous ascorbic acid and urea clearance tests.

\section{METHOD}

As subjects, there were used eight patients previously hospitalized for some form of renal disease, and four normal individuals serving as controls.

\section{Ascorbic acid utilization test}

This was not done at this time on the normal subjects, two of whom (Subjects 9 and 10, Table II) had been tested previously. The utilization index for normals has been found by Sendroy and Schultz (2) to vary only within the average limits of $67.5 \pm 5.5$. The index was determined, however, for each patient, it being ascertained that the diet had been adequate with respect to ascorbic acid, prior to the excretion test. Of these cases, none was disturbed by digestive (anorexia, etc.) or metabolic (fever, etc.) disorders during the test.

The urinary excretion test was carried out, with a few modifications, according to the technique of Sendroy and Schultz (2). The diet during the test contained the minimum of ascorbic acid (less than $12 \mathrm{mgm}$. daily). After 48 hours, this was supplemented, for the next seven days, by the addition of $250 \mathrm{mgm}$. of "Redoxon" ( $l$ ascorbic acid, Hoffman-La Roche) daily, taken after breakfast. Fluid intake was somewhat restricted.

Collection of urine specimens. At the beginning of a test period, the urine voided at 8 a.m. was discarded. The last specimen for every 24-hour period was obtained at 8 a.m. Although Sendroy and Schultz's method (2) of collection has been shown to give satisfactory results, the following procedure, involving the use of a preservative to prevent ascorbic acid oxidation, was adopted because of its greater convenience and accuracy.

All of the urine voided was quickly transferred to, and stored in, $750 \mathrm{cc}$. specimen bottles. Usually, two bottles sufficed for the 24-hour collection. Each bottle was prepared for use by the prior addition of a preservative mixture consisting of $75 \mathrm{cc}$. of $5 \mathrm{~N} \mathrm{H}_{2} \mathrm{SO}_{4}$ solution (approximately 135 cc. of concentrated $\mathrm{H}_{2} \mathrm{SO}_{4}$ per liter), 0.75 cc. of 0.1 м 8-hydroxyquinoline solution (1.45 grams per $100 \mathrm{cc} .95$ per cent ethyl alcohol), ${ }^{3}$ and $1.5 \mathrm{cc}$. of toluene,

${ }^{3}$ Sulfuric acid and 8-hydroxyquinoline were suggested for use in urine analyses by Dr. E. S. Guzman Barron (see "Experimental" section). We have found alcohol a better solvent for 8-hydroxyquinoline than dilute sulfuric acid, in that solutions could be kept for use for at least one week without visible color change. Toluene was added to minimize bacterial action. c.p. Between voidings, and between the time of the last specimen collection and that of the analysis, the bottles were kept stoppered, in a refrigerator, at about $5^{\circ} \mathrm{C}$.

Titration of urine specimens. For analysis, the total 24-hour output (together with the added preservative) was mixed and measured in a graduated cylinder, from which duplicate samples of from 2 to $20 \mathrm{cc}$. were withdrawn, depending on the concentration of ascorbic acid present. Water, to bring the total volume to about 48 cc., and 2.5 cc. of glacial acetic acid ${ }^{4}$ were added. Titration with 2,6-dichlorophenol indophenol was carried out as described by Sendroy and Schultz (2), except that the indicator was standardized against a solution of ascorbic acid ("Redoxon") in 2 per cent metaphosphoric acid instead of in water.

\section{Urea and ascorbic acid clearance tests}

Simultaneous clearances were done on all subjects, patients and normals, after the completion of the urinary excretion studies. When the clearance test was begun some time after the utilization test was finished, large doses of ascorbic acid were fed during the interval, in order to avoid the complications of a possible "undersaturation."

The clearances were determined by the technique used by Van Slyke and coworkers, with modifications as described for urea by Van Slyke, Page, Hiller, and Kirk (13). On the day of the experiment, the subject was deprived of breakfast. At 6 a.m. he received $200 \mathrm{cc}$. of water per os, followed at 7 a.m. by $500 \mathrm{mgm}$. of " Redoxon" and $200 \mathrm{cc}$. of water. At 8 a.m. an additional $200 \mathrm{cc}$. of water were given. At 9 a.m. the first of two one-hour periods was started. At the middle of each period of urine collection, blood was drawn.

Urine analyses. The urine was transferred, immediately after collection, to a measuring cylinder (containing no preservative), covered with mineral oil, and then immediately analyzed for ascorbic acid as described above. Urea analyses were done according to Van Slyke and Kugel (14).

Plasma analyses. Blood was drawn into a syringe and immediately separated into two portions. For the ascorbic acid analysis, $7 \mathrm{cc}$. were placed in a centrifuge tube containing $14 \mathrm{mgm} . \mathrm{K}_{2} \mathrm{C}_{2} \mathrm{O}_{4}$ and quickly centrifuged ( 5 minutes). Of the plasma, 3 cc. were deproteinized with metaphosphoric acid (15) and immediately centrifuged for 15 minutes. Five cc. samples of the supernatant were titrated with a 2,6-dichlorophenol indophenol solution (approximately 0.0065 gram per $100 \mathrm{cc}$.) Blank determinations were done with 2 per cent metaphosphoric acid. The indicator was standardized against a $1 \mathrm{cc}$. sample of ascorbic acid solution (about $10 \mathrm{mgm}$., accurately weighed, in $200 \mathrm{cc}$. of 2 per cent $\mathrm{HPO}_{8}$ ), plus 4 cc. of 2 per cent $\mathrm{HPO}_{3}$. Urea analyses were done on the plasma or serum from another portion of blood (13).

4 Glacial acetic acid is more convenient to use, and less expensive than trichloracetic acid, which has been used in various laboratories (2). 


\section{EXPERIMENTAL}

The preservation of ascorbic acid in urine. In studying some of the factors involved in the oxidation of ascorbic acid in the average, untreated urine over varying periods of time prior to analysis, Sendroy and Schultz (2) showed that the oxygen tension was the most important. They were able to retard oxidation by exclusion of air from the sample bottles, which were stored overnight in the cold. Although their procedure gave satisfactory results, it was thought desirable to use a simpler technique, and one which would eliminate the loss of titratable ascorbic acid, in the presence of air, by inhibition of the action of oxidative catalysts such as copper $(16,17)$.

Fujita and Iwatake (18) found that 2 per cent metaphosphoric acid greatly retarded spontaneous oxidation of ascorbic acid solutions, a fact confirmed by Musulin and King (19). We endeavored to use this material as a protective agent for urinary ascorbic acid. Solid $\mathrm{HPO}_{3}$, to make a concentration of 2 or 5 per cent in solution, was added to urine samples, with and without added ascorbic acid. Portions of the urine samples were immediately titrated with 2,6-dichlorophenol indophenol. The remainder was then stored for about 24 hours in the refrigerator, in specimen bottles exposed either to onehalf volume of air or merely to the bubble left when a completely filled bottle was stoppered. Varying amounts of toluene were also used. After 24 hours, the samples were again analyzed for ascorbic acid. The results are indicated in Table I. Apparently, under these conditions, there is a loss of titratable material equivalent in concentration to from 0 to $3 \mathrm{mgm}$. of ascorbic acid per 100 cc. of urine. The percentage loss will therefore tend to be greater in the samples of lower concentrations although the variation from urine to urine is such that no rule of prediction may be applied. In general, it may be concluded from these results that in the presence of air, at low temperature $\left(5^{\circ}\right.$ C. $)$ over a period of 24 hours, ascorbic acid may be preserved in urine, in the presence of 5 per cent metaphosphoric acid and 0.2 per cent toluene, with a probable loss of 6 per cent.

While we were engaged in the preliminary studies of the effect of metaphosphoric acid, Dr. E. S. G. Barron informed us that he had already found a suitable preservative for urinary ascorbic acid, and kindly suggested its use for our studies, which we were anxious to do while the clinical material was available. The inhibitory effect of 8-hydroxyquinoline on ascorbic acid oxidation in vegetable and fruit juices has since been reported by Barron, Barron, and Klemperer (17). The experimental data in support of the use of 8-hydroxyquinoline and sulfuric acid for urine analysis have not as yet been published from their laboratory. However, in the meanwhile, it will suffice for us to say that we have thoroughly tested the preservative; that we have found it, with toluene and storage in the cold, more effective than any other procedure in preventing the oxidation of ascorbic acid in the varying concentrations found in urine after a test dose; that the loss of titratable ascorbic acid
TABLE I

The preservation of ascorbic acid in urine kept at $5^{\circ} \mathrm{C}$. for 24 hours, with added metaphosphoric acid

\begin{tabular}{|c|c|c|c|c|c|c|c|}
\hline \multirow{3}{*}{$\underset{\substack{\text { numple } \\
\text { ber }}}{\text { Sample }}$} & \multirow{2}{*}{\multicolumn{2}{|c|}{$\begin{array}{l}\text { Final con- } \\
\text { centration } \\
\text { in urine } \\
\text { of added }\end{array}$}} & \multirow{3}{*}{$\begin{array}{l}\text { Amount of air } \\
\text { left in speci- } \\
\text { men bottle }\end{array}$} & \multicolumn{4}{|c|}{ Ascorbic acid concentration } \\
\hline & & & & \multirow{2}{*}{ Initial } & \multirow{2}{*}{ Final } & \multirow{2}{*}{ Loss } & \multirow{2}{*}{$\begin{array}{l}\text { Part } \\
\text { of ini- } \\
\text { tial } \\
\text { pre- } \\
\text { served }\end{array}$} \\
\hline & $\mathrm{HPO}_{3}$ & $\begin{array}{l}\text { Tol- } \\
\text { uene }\end{array}$ & & & & & \\
\hline & $\begin{array}{l}\text { per } \\
\text { cent }\end{array}$ & $\begin{array}{l}\text { per } \\
\text { cent }\end{array}$ & & $\begin{array}{l}\text { mgm. } \\
\text { per } \\
100 \mathrm{cc} .\end{array}$ & $\begin{array}{l}\text { mgm. } \\
\text { per } \\
100 \mathrm{cc} .\end{array}$ & $\begin{array}{c}\text { mgm. } \\
\text { per } \\
100 \mathrm{cc} .\end{array}$ & $\begin{array}{l}\text { per } \\
\text { cent }\end{array}$ \\
\hline 1 & $\begin{array}{l}2 \\
2\end{array}$ & $\begin{array}{l}0.3 \\
1.0\end{array}$ & $\begin{array}{l}\text { Bubble } \\
\text { Half volume }\end{array}$ & 28.2 & $\begin{array}{l}25.3 \\
25.1\end{array}$ & $\begin{array}{l}2.9 \\
3.1\end{array}$ & $\begin{array}{l}89.7 \\
89.0\end{array}$ \\
\hline 2 & $\begin{array}{l}2 \\
2\end{array}$ & \begin{tabular}{l|}
0.3 \\
1.0
\end{tabular} & $\begin{array}{l}\text { Bubble } \\
\text { Half volume }\end{array}$ & 30.5 & $\begin{array}{l}29.3 \\
30.7\end{array}$ & $\begin{array}{r}1.2 \\
+0.2\end{array}$ & $\begin{array}{r}96.1 \\
100.7\end{array}$ \\
\hline 3 & $\begin{array}{l}2 \\
2\end{array}$ & $\begin{array}{l}0.3 \\
1.0\end{array}$ & $\begin{array}{l}\text { Bubble } \\
\text { Half volume }\end{array}$ & 28.6 & $\begin{array}{l}26.8 \\
26.6\end{array}$ & $\begin{array}{l}1.8 \\
2.0\end{array}$ & $\begin{array}{l}93.7 \\
93.0\end{array}$ \\
\hline 4 & $\begin{array}{l}2 \\
2\end{array}$ & $\begin{array}{l}0.3 \\
1.0\end{array}$ & $\begin{array}{l}\text { Bubble } \\
\text { Half volume }\end{array}$ & 32.3 & $\begin{array}{l}30.4 \\
30.3\end{array}$ & $\begin{array}{l}1.9 \\
2.0\end{array}$ & $\begin{array}{l}94.1 \\
93.8\end{array}$ \\
\hline 5 & $\begin{array}{l}2 \\
2 \\
5 \\
5\end{array}$ & $\begin{array}{l}1.0 \\
1.0\end{array}$ & $\begin{array}{l}\text { Half volume } \\
\text { Half volume } \\
\text { Half volume } \\
\text { Half volume }\end{array}$ & 13.7 & $\begin{array}{l}13.4 \\
13.4 \\
13.5 \\
13.5\end{array}$ & $\begin{array}{l}0.3 \\
0.3 \\
0.2 \\
0.2\end{array}$ & $\begin{array}{l}97.8 \\
97.8 \\
98.6 \\
98.6\end{array}$ \\
\hline 6 & $\begin{array}{l}2 \\
2 \\
5 \\
5\end{array}$ & $\begin{array}{l}1.0 \\
1.0\end{array}$ & $\begin{array}{l}\text { Half volume } \\
\text { Half volume } \\
\text { Half volume } \\
\text { Half volume }\end{array}$ & 8.76 & $\begin{array}{l}7.70 \\
7.70 \\
7.92 \\
8.02\end{array}$ & $\begin{array}{l}1.06 \\
1.06 \\
0.84 \\
0.74\end{array}$ & $\begin{array}{l}87.9 \\
87.9 \\
90.4 \\
91.6\end{array}$ \\
\hline
\end{tabular}

is usually limited to 2 to 5 per cent over a period of 24 to 48 hours. Moreover, we have found that the concentration of preservative may be increased at least five times without affecting the titration. It therefore does not matter if the $750 \mathrm{cc}$. specimen bottles are not filled to capacity.

Since the urine of nephritic patients is usually albuminous, the effect of protein on the titration of ascorbic acid in urine was investigated. For this purpose, several 24-hour specimens of urine containing from 0.86 gram to 10.38 grams of protein per liter were collected. Because of the sulfuric acid in the preservative, some protein was already precipitated out when the specimens were received in the laboratory. With stirring, this material was uniformly distributed throughout the fluid, which was then divided into three portions. Titrations were done on one portion immediately, on another after separation from the solid matter by centrifugation, and on another after deproteinization with metaphosphoric acid (to make a 2 per cent concentration). The results of the titrations of the three portions were practically identical for the several specimens tested. Comparisons of freshly voided albuminous urines, with and without deproteinization with trichloroacetic acid failed to show any differences in the titration values.

The preservation of ascorbic acid in plasma. Following 'Fujita and Iwatake's observation (18) concerning its stabilizing influence in ascorbic acid solutions, it seemed logical to employ metaphosphoric acid for plasma 
analyses, since it is also an adequate blood deproteinizing agent, as has been shown by Hiller and Van Slyke (20). When Farmer and Abt's revised procedure was published (15), we had already finished experiments, the results of which were in agreement with their work. In confirmation of their findings, and those of Pijoan, Townsend, and Wilson (21), we observed a loss, on standing, of substance titratable with 2,6-dichlorophenol indophenol. This loss was presumably owing to oxidation of ascorbic acid. On the assumption that such was the case, although no proof exists that it is ascorbic acid that is lost under these conditions, it seemed that the most reliable values were those obtained for samples deproteinized within the minimum time after withdrawal of blood.

In order to prevent such losses of titratable ascorbic acid, Pijoan and Klemperer (22) have recommended as an inhibitor the use of 0.1 per cent $\mathrm{KCN}$ in blood before deproteinization. In testing their procedure, we did find increased values as a result of adding $\mathrm{KCN}$ to blood, but $\mathrm{KCN}$ did not prevent the loss of titratable ascorbic acid which occurred when plasma stood for 2 hours before deproteinization. Furthermore, blank analyses with the protein precipitant and $\mathrm{KCN}$ were too high and too variable to afford confidence in the reliability of the results. More recently, others $(23,24)$ have questioned the efficacy of adding $\mathrm{KCN}$ to whole blood when ascorbic acid titrations of metaphosphoric acid filtrates are made with 2,6-dichlorophenol indophenol. The first group of workers (Friedman, et al.) found that $\mathrm{KCN}$ increased the amount of dye required up to physiological concentrations in plasma. Beyond that, at higher concentrations, $\mathrm{KCN}$ filtrates gave lower values than the "unprotected" ones. In all cases, whatever values were obtained remained constant for almost three hours.

Farmer and Abt (24) have come to the conclusion that when $\mathrm{KCN}$ is used with their procedure, the inhibitor invalidates results. They found that $\mathrm{KCN}$ does not prevent loss of ascorbic acid from blood on standing, although it does decolorize 2,6-dichlorophenol indophenol in $\mathrm{HPO}_{8}$ solution and in blood plasma filtrates, thereby increasing the amount of ascorbic acid apparently present. Our own results were similar to theirs. It appears, from the foregoing, that $\mathrm{KCN}$, while not preventing loss of ascorbic acid, may, under certain circumstances by its decolorizing effect on the indicator, exhibit a compensating "stabilizing" effect. At the present time, therefore, for dependable ascorbic acid values by the method of Farmer and Abt (15), it would seem best to follow their recommendations $(15,24)$ that the blood be centrifuged immediately after withdrawal, the plasma separated, and deproteinization carried out as quickly as possible.

\section{RESULTS}

From the results shown in Table II and Figure 1 , there is a distinct, although only roughly quantitative, relationship between the utilization index, as found by urinary excretion studies, and the

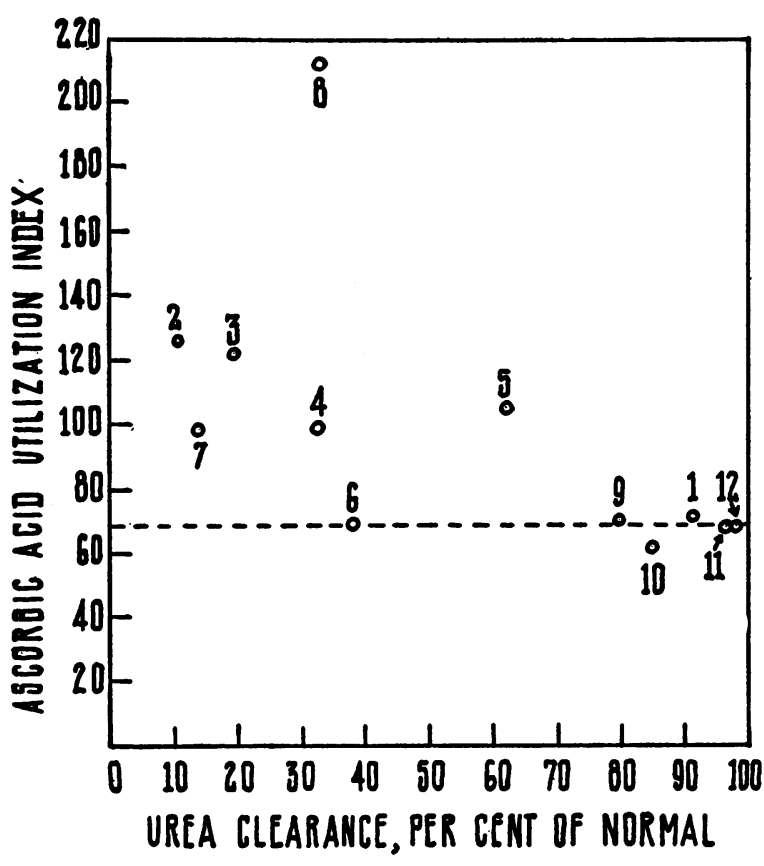

Fig. 1. Relattonship between Results of Urinary Excretion Tests for Ascorbic ACtd, As Indicated by THE Ascorbic Acid Utilization Index, aNd Kidney Function, as Indicated by Urea Clearance DeterMINATIONS

The dotted line follows the average, normal value for the index. The numbers of the points refer to the subjects of Table II.

kidney function as judged by the maximum or standard urea clearance. With the exception of Case 6, the subjects with low percentages of normal urea clearance show a subnormal urinary excretion of ascorbic acid. The evidence is sufficient to indicate that under otherwise normal conditions of ascorbic acid intake and output, when there is impairment of renal function, as in these cases of nephritis, there is a corresponding ascorbic acid retention, and a lowered excretion in the urine.

If the ratios of ascorbic acid clearance relative to urea clearance be calculated (Column 14, Table II) there is found a more marked and somewhat more quantitative difference in the renal excretion of ascorbic acid of the two groups, normal and nephritic. When kidney function is approximately normal, the ratio is about 0.5 . For the nephritic group, the ratio is about 1.1. The increase in the ratio varies with decrease in renal function. These findings are 
TABLE II

Results of tests of ascorbic acid utilization and simultaneous ascorbic acid and urea clearance

\begin{tabular}{|c|c|c|c|c|c|c|c|c|c|c|c|c|c|}
\hline 1 & 2 & 3 & 4 & 5 & 6 & 7 & 8 & 9 & 10 & 11 & 12 & 13 & 14 \\
\hline \multirow{4}{*}{$\begin{array}{c}\text { Sub- } \\
\text { ject } \\
\text { num- } \\
\text { ber }\end{array}$} & \multirow{4}{*}{ Sex } & \multirow{4}{*}{ Age } & \multirow{4}{*}{\begin{tabular}{|} 
Body \\
weight
\end{tabular}} & \multirow{4}{*}{ Condition } & \multirow{2}{*}{\multicolumn{2}{|c|}{$\begin{array}{c}\text { 12-hour urine } \\
\text { specimen } \\
\text { contained }\end{array}$}} & \multirow{4}{*}{\begin{tabular}{|c|} 
Utili- \\
zation \\
index
\end{tabular}} & \multicolumn{6}{|c|}{ Clearance determinations* } \\
\hline & & & & & & & & \multirow{2}{*}{\multicolumn{2}{|c|}{$\begin{array}{l}\text { Plasma } \\
\text { analysis }\end{array}$}} & \multirow{3}{*}{$\begin{array}{c}\text { As- } \\
\text { corbic } \\
\text { acid } \\
\text { clear- } \\
\text { ance } \\
\frac{U V c}{P} \\
P\end{array}$} & \multirow{2}{*}{\multicolumn{2}{|c|}{$\begin{array}{c}\text { Urea } \\
\text { clearance }\end{array}$}} & \multirow{3}{*}{$\begin{array}{c}\begin{array}{c}\text { Clearance } \\
\text { ratio: } \\
\text { ascorbic acid } \\
\text { urea }\end{array}\end{array}$} \\
\hline & & & & & \multirow{2}{*}{$\begin{array}{c}\text { Red } \\
\text { blood } \\
\text { cells }\end{array}$} & \multirow[b]{2}{*}{ Protein } & & & & & & & \\
\hline & & & & & & & & $\begin{array}{c}\text { As- } \\
\text { corbic } \\
\text { acid }\end{array}$ & Urea & & $\frac{U V c}{P}$ & $\begin{array}{c}\text { Per } \\
\text { cent of } \\
\text { normal }\end{array}$ & \\
\hline 1 & $\mathbf{F}$ & $\begin{array}{c}\text { years } \\
18\end{array}$ & $\begin{array}{c}\text { kgm. } \\
52\end{array}$ & $\begin{array}{l}\text { Latent, degenerative Bright's } \\
\text { disease }\end{array}$ & $\begin{array}{c}\text { millions } \\
0.4\end{array}$ & $\begin{array}{c}\text { grams } \\
2.7\end{array}$ & 71 & $\begin{array}{c}\underset{\text { mem. }}{\text { per }} \\
100 \mathrm{cc} . \\
1.69\end{array}$ & $\mid$\begin{tabular}{c|}
$m g m$. \\
$p e r$ \\
100 \\
$c c$. \\
12.2
\end{tabular} & 27.5 & $|68.6|$ & 92 & 0.40 \\
\hline 2 & $\mathbf{F}$ & 25 & 65 & $\begin{array}{l}\text { Chronic, hemorrhagic Bright's } \\
\text { disease }\end{array}$ & 0.8 & 4.5 & 126 & 2.53 & 53.9 & 6.7 & 5.8 & 11 & 1.16 \\
\hline 3 & $\mathbf{F}$ & 30 & 58 & $\begin{array}{l}\text { Chronic, hemorrhagic Bright's } \\
\text { disease }\end{array}$ & 0.075 & 4.0 & 122 & $\begin{array}{l}1.63 \\
1.49\end{array}$ & $\begin{array}{l}37.7 \\
41.7\end{array}$ & \begin{tabular}{r|}
8.8 \\
16.0
\end{tabular} & $\begin{array}{r}7.4 \\
15.9 \\
\end{array}$ & $\begin{array}{l}18 \\
21\end{array}$ & $\begin{array}{l}1.19 \\
1.00\end{array}$ \\
\hline 4 & $\mathbf{M}$ & 24 & 60 & $\begin{array}{l}\text { Chronic, hemorrhagic Bright's } \\
\text { disease }\end{array}$ & 0.2 & 0.9 & 98 & 2.46 & $\begin{array}{l}34.0 \\
31.7\end{array}$ & 27.1 & \begin{tabular}{|l|}
22.8 \\
24.2
\end{tabular} & $\begin{array}{l}31 \\
32\end{array}$ & $\begin{array}{l}1.25 \\
1.12\end{array}$ \\
\hline 5 & $\mathbf{M}$ & 24 & 57 & $\begin{array}{l}\text { Chronic, hemorrhagic Bright's } \\
\text { disease }\end{array}$ & 25.0 & 1.0 & 105 & $\begin{array}{l}2.50 \\
1.93\end{array}$ & $\begin{array}{l}23.3 \\
22.3\end{array}$ & $\begin{array}{l}31.8 \\
38.9\end{array}$ & $\begin{array}{l}31.8 \\
39.7\end{array}$ & $\begin{array}{l}69 \\
56\end{array}$ & $\begin{array}{l}1.00 \\
0.98\end{array}$ \\
\hline 6 & $\mathbf{M}$ & 19 & 60 & $\begin{array}{l}\text { Chronic, hemorrhagic Bright's } \\
\text { disease }\end{array}$ & 16.0 & 3.9 & 69 & $\begin{array}{l}1.11 \\
1.22 \\
\end{array}$ & $\begin{array}{l}31.4 \\
31.2 \\
\end{array}$ & $\begin{array}{l}26.6 \\
26.9 \\
\end{array}$ & $\begin{array}{l}25.9 \\
25.3 \\
\end{array}$ & $\begin{array}{l}42 \\
34 \\
\end{array}$ & $\begin{array}{l}1.03 \\
1.06 \\
\end{array}$ \\
\hline 7 & $\mathbf{M}$ & 24 & 56 & $\begin{array}{l}\text { Chronic, hemorrhagic Bright's } \\
\text { disease }\end{array}$ & 100.0 & 3.2 & 98 & $\begin{array}{l}2.54 \\
2.49\end{array}$ & $\begin{array}{l}88.8 \\
89.0\end{array}$ & $\begin{array}{r}10.3 \\
9.4\end{array}$ & $\begin{array}{l}9.3 \\
8.5\end{array}$ & $\begin{array}{l}14 \\
14\end{array}$ & $\begin{array}{l}1.11 \\
1.11\end{array}$ \\
\hline 8 & $\mathbf{M}$ & 51 & 48 & $\begin{array}{l}\text { Arteriosclerotic Bright's dis- } \\
\text { ease }\end{array}$ & & 3.2 & 212 & $\begin{array}{l}3.08 \\
3.10\end{array}$ & $\begin{array}{l}40.1 \\
31.3\end{array}$ & $\begin{array}{l}18.1 \\
20.5\end{array}$ & $\begin{array}{l}17.3 \\
24.7\end{array}$ & $\begin{array}{l}33 \\
33\end{array}$ & $\begin{array}{l}1.05 \\
0.83 \\
\end{array}$ \\
\hline 9 & $\mathbf{M}$ & 28 & 70 & Normal & & & (70) & 1.70 & 13.1 & 20.8 & 56.6 & 80 & 0.37 \\
\hline 10 & $\mathbf{M}$ & 36 & 66 & Normal & & & $(61)$ & $\begin{array}{l}1.71 \\
1.63\end{array}$ & $\begin{array}{l}11.0 \\
10.5\end{array}$ & $\begin{array}{l}36.5 \\
28.2\end{array}$ & $\begin{array}{l}60.7 \\
56.8\end{array}$ & $\begin{array}{l}81 \\
89\end{array}$ & $\begin{array}{l}0.60 \\
0.50\end{array}$ \\
\hline 11 & $\mathbf{M}$ & 29 & 70 & Normal & & & (68) & 1.86 & 13.2 & 44.1 & 61.9 & 97 & 0.71 \\
\hline 12 & $\mathbf{M}$ & 29 & 76 & Normal & & & (68) & 1.54 & 8.8 & 44.6 & 73.5 & 98 & 0.61 \\
\hline
\end{tabular}

* The absolute values for the clearances are all calculated as $U V c / P$. The "per cent of normal," Column 13, is calculated by either the standard or maximum urea clearance equation (25), according to the urine volume.

consistent with the observations of Friedman, McGoey, and Ralli (11), and of Ralli, Friedman, and Rubin (12), that the ascorbic acid clearance increases with rising plasma concentration until a limiting value is reached.

Under the conditions of our experiments, i.e., with nephritic subjects in whom the renal lesions were in varying degrees of activity, the excretion of ascorbic acid varied with the functional capacity of the kidneys. Presumably, any disease or condition which reduces renal function, e.g., Addison's disease, would also impair the excre- tion of ascorbic acid. In such cases, excretion tests for ascorbic acid would give results which would be false with respect to the nutritional state. We suggest, whenever excretion tests give values indicative of ascorbic acid deficit in the body, that the tests be further controlled by adequate renal function measurements.

\section{SUMMARY}

Abnormally slow excretion of administered ascorbic acid does not necessarily indicate a low ascorbic acid content of the body when renal 
function is low ; because renal damage retards excretion, even when no ascorbic acid deficit exists. The effect of lowered kidney function on the ascorbic acid clearance runs approximately parallel to the effect on the urea clearance.

\section{BIBLIOGRAPHY}

1. Harris, L. J., Ray, S. N., and Ward, A., The excretion of Vitamin $C$ in human urine and its dependence on the dietary intake. Biochem. J., 1933, 27, 2011.

2. Sendroy, J., Jr., and Schultz, M. P., Studies of ascorbic acid and rheumatic fever. I. Quantitative index of ascorbic acid utilization in human beings and its application to the study of rheumatic fever. J. Clin. Invest., 1936, 15, 369.

3. Drigalski, W. v., Uber Vitamin C im Urin Von Gesunden und Kranken. Klin. Wchnschr., 1935, 14, 338.

4. Siwe, S. A., Das Verhalten des C-Vitamins bei Morbus Addesoni. Klin. Wchnschr., 1935, 14, 1311.

5. Wilkinson, J. F., Manch, M. D., and Ashford, C. A., Vitamin C deficiency in Addison's disease. Lancet, 1936, 2, 967.

6. Van Eekelen, M., On the amount of ascorbic acid in blood and urine. The daily human requirements for ascorbic acid. Biochem. J., 1936, 30, 2291.

7. Lund, $\mathrm{H}$., Eine quantitative und spezifische Methode zur Ascorbinsäuretitration im Harn und zur Bestimmung des Schwellenwertes. Klin. Wchnschr., 1937, 16, 1085.

8. Faulkner, J. M., and Taylor, F. H. L., Observations on the renal threshold for ascorbic acid in man. J. Clin. Invest., 1938, 17, 69.

9. Wright, I. S., Lilienfeld, A., and MacLenathen, E., Determination of vitamin $\mathrm{C}$ saturation. A fivehour test after an intravenous test dose. Arch. Int. Med., 1937, 60, 264.

10. Wright, I. S., and MacLenathen, E., Vitamin C saturation-Kidney retention after an intravenous test dose of ascorbic acid. Proc. Soc. Exper. Biol. and Med., 1938, 38, 55.

11. Friedman, G. J., McGoey, C., and Ralli, E. P., The clearance of Vitamin $\mathrm{C}$ by the human kidney. Am. J. Physiol. (Proc.), 1938, 123, 71.
12. Ralli, E. P., Friedman, G. J., and Rubin, S. H., The mechanism of Vitamin $\mathrm{C}$ excretion in man studied by simultaneous Vitamin $\mathrm{C}$ and inulin clearances. J. Clin. Invest. (Proc.), 1938, 17, 504.

13. Van Slyke, D. D., Page, I. H., Hiller, A., and Kirk, E., Studies of urea excretion. IX. Comparison of urea clearances calculated from the excretion of urea, of urea plus ammonia and of nitrogen determinable by hypobromite. J. Clin. Invest., 1935, 14, 901.

14. Van Slyke, D. D., and Kugel, V. H., Improvements in manometric micro-Kjeldahl and blood urea methods. J. Biol. Chem., 1933, 102, 489.

15. Farmer, C. J., and Abt, A. F., Determination of reduced ascorbic acid in small amounts of blood. Proc. Soc. Exper. Biol. and Med., 1936, 34, 146.

16. Barron, E. S. G., De Meio, R. H., and Klemperer, F., Studies on biological oxidations. V. Copper and hemochromogens as catalysts for the oxidation of ascorbic acid. The mechanism of the oxidation. J. Biol. Chem., 1936, 112, 625.

17. Barron, E. S. G., Barron, A. G., and Klemperer, F., Studies on biological oxidation. VII. The oxidation of ascorbic acid in biological fluids. J. Biol. Chem., 1936, 116, 563.

18. Fujita, A., and Iwatake, D., Uber die Bestimmung von Vitamin C mittels 2,6-Dichlorophenolindophenol. Biochem. Ztschr., 1935, 277, 293.

19. Musulin, R. R., and King, C. G., Metaphosphoric acid in the extraction of Vitamin C. J. Biol. Chem., 1936, 116, 409.

20. Hiller, A., and Van Slyke, D. D., A study of certain protein precipitants. J. Biol. Chem., 1922, 53, 253.

21. Pijoan, M., Towsend, S. A., and Wilson, A., Determination of reduced ascorbic acid in blood. Proc. Soc. Exper. Biol. and Med., 1936, 35, 224.

22. Pijoan, M., and Klemperer, F., Determination of blood ascorbic acid. J. Clin. Invest., 1937, 16, 443.

23. Friedman, G. J., Rubin, S. H., and Kees, W., Effect of addition of KCN to whole blood on indophenolreducing power of plasma. Proc. Soc. Exper. Biol. and Med., 1938, 38, 358.

24. Farmer, C. J., and Abt, A. F., Invalidation of plasma ascorbic acid values by use of potassium cyanide. Proc. Soc. Exper. Biol. and Med., 1938, 38, 399.

25. Peters, J. P., and Van Slyke, D. D., Quantitative Clinical Chemistry. Vol. I. Interpretations. Williams and Wilkins Co., Baltimore, 1931, D. 335. 